Western North American Naturalist 69(2), (c) 2009, pp. 223-234

\title{
ANT ASSEMBLAGES IN INTACT BIG SAGEBRUSH AND CONVERTED CHEATGRASS-DOMINATED HABITATS IN TOOELE COUNTY, UTAH
}

\author{
Steven M. Ostoja ${ }^{1,2,3}$, Eugene W. Schupp ${ }^{1,2}$, and Kelly Sivy ${ }^{1}$
}

\begin{abstract}
Biological invasions are one of the greatest threats to native species in natural ecological systems. One of the most successful invasive species is Bromus tectorum L. (cheatgrass), which is having marked impacts on native plant communities and ecosystem processes. However, we know little about the effects of this invasion on native animal species in the Intermountain West. Because ants have been used to detect ecological change associated with anthropogenic land use, they seem well suited for a preliminary evaluation of the consequences of cheatgrass-driven habitat conversion. In our study, we used pitfall traps to assess ant community assemblages in intact sagebrush and nearby cheatgrass-dominated vegetation. Ant abundance was about 10-fold greater in cheatgrass-dominated plots than in sagebrush plots. We also noted differences in diversity and evenness between habitat types at both the species and the functional-group levels of organization. At the species level, Shannon's diversity index was greater in sagebrush plots than in cheatgrass-dominated plots. However, at the functional-group level, Simpson's and Shannon's diversity indices and the Brillouin evenness index were greater in cheatgrass-dominated plots than in sagebrush plots. Further, common species / functional groups tended to be more abundant while less common species / functional groups tended to be less abundant in cheatgrass-dominated plots compared to intact sagebrush plots. Patterns appear to be at least partially related to resource availabilities. This initial survey of ant communities from intact-native and altered vegetation types may be indicative of similar trends of biodiversity shifts throughout the Intermountain West where cheatgrass has successfully replaced native species. We also discuss the implications of ant communities on land management activities, specifically in the context of aridland restoration.
\end{abstract}

Key words: ants, invertebrates, ant communities, invasion, cheatgrass, Bromus tectorum, big sagebrush, Artemisia tridentata, Great Basin desert, ecological restoration.

Initially introduced in contaminated livestock feed, the Eurasian annual grass Bromus tectorum L. (cheatgrass) has become a very successful invader throughout the United States (Novak and Mack 2001). Climate change, overgrazing by livestock, and generally poor management practices initially facilitated the invasion of B. tectorum into sagebrush habitats (Billings 1990, Fleischner 1994, Knapp 1996), but the subsequent conversion of sagebrush habitat to B. tectorum-dominated grasslands throughout the Intermountain West is most closely tied to fires (D'Antonio and Vitousek 1992, Fleischner 1994, Brooks et al. 2004). It is estimated that about $40,000,000$ ha have been invaded by or converted to near monocultures of B. tectorum within this region (Link et al. 2006). Because of the extensive fine fuels produced by B. tectorum, invaded communities are subject to frequent fires that reinforce the conversion (Pellant 1989).

As one of the greatest threats to species diversity, B. tectorum threatens the historically rich biotic diversity once a part of the Intermountain West (Vale 1975, Billings 1990). Many animals dependent on sagebrush and associated vegetation are thought to have been greatly reduced or eliminated altogether because of cheatgrass invasion (Pimentel et al. 2000). Reports indicate that the conversion of sagebrush habitat to $B$. tectorum negatively impacts native animal species such as sage grouse and small mammals (Yensen et al. 1992, Wirth and Pyke 2003, Ostoja 2008), but there is little understanding of the effects of this conversion on less charismatic species like invertebrates. Although we assume that invertebrate responses are similar to mammalian and avian responses, there are few data evaluating this assumption.

\footnotetext{
${ }^{1}$ Department of Wildland Resources, Utah State University, Logan, UT 84322

${ }^{2}$ Ecology Center, Utah State University, Logan, UT 84322.

${ }^{3}$ Present address: U.S. Geological Survey, Western Ecological Research Center, Yosemite Field Station, 5083 Foresta Road, El Portal, CA 95318-0700. E-mail: sostoja@usgs.gov
} 
Terrestrial invertebrates can be good indicators of ecological change associated with land-use activities such as mining, restoration, and grazing (Andersen and Majer 2004). Specifically, ants have received much attention from ecologists as bioindicators in land management and restoration because they are thought to respond in ecologically interpretable ways to environmental changes associated with disturbances (Bestelmeyer and Wiens 1996, 2001, King et al. 1998, Hoffmann and Andersen 2003). Furthermore, it is thought that ants are good indicators of the potential responses of a variety of species across very different taxonomic groups. For example, Andersen and Sparling (1997) found a relationship between aboveground ant activity and belowground decomposition processes at altered sites and a negative correlation between ant species richness and soil microbial biomass across a range of undisturbed sites. This may be suggestive of the consequences of differentiating between withinhabitat variation due to disturbance and variation across unique habitats when researchers select for bioindicators of ecological change (Andersen 1997, Andersen and Sparling 1997, Andersen et al. 2002). Thus, in the face of a changing sagebrush desert landscape throughout the Great Basin, ants are an appropriate group to evaluate.

In this study, we evaluated ant communities in intact sagebrush stands and in adjacent areas converted to B. tectorum in the Great Basin of western Utah. In addition to their value as bioindicators, some species of ants harvest large quantities of seed. Because seed application is a frequent restoration strategy in these invaded habitats, understanding changes in ant communities might be especially relevant to restoration efforts. We predicted that (1) overall species composition and diversity of ants in cheatgrass-dominated sites would be lower than in nearby intact sagebrush sites but also that (2) conspicuous species (i.e., Pogonomyrmex occidentalis) would be more abundant in cheatgrass-dominated sites than in sagebrush sites. The first prediction was based on findings that vertebrate abundance and diversity were lower in cheatgrass-dominated communities relative to sagebrush communities (Ostoja 2008) and that insect abundance and diversity are generally greater in areas of greater plant diversity and structural complexity
(Murdoch et al. 1972, Crisp et al. 1998, Koricheva et al. 2000, Tews et al. 2004, Perner et al. 2005, Wenninger and Inouye 2008). The second prediction was based on previous findings that $P$. occidentalis mound densities were significantly higher in cheatgrass than in sagebrush locations (Ostoja unpublished data) and that species richness and abundance of rodents, potential competitors for seed resources, were significantly lower in cheatgrass monocultures (Ostoja 2008).

\section{Methods \\ Study Site}

This study was conducted in Rush Valley in west central Utah in an area referred to as Vernon Hills, Tooele County (Zone 12, 384335E, $4438482 \mathrm{~N})$, approximately $155 \mathrm{~km}$ southwest of Salt Lake City, Utah. Six 1.5-ha study plots were established, 3 in intact sagebrush vegetation ("sagebrush" hereafter) and 3 in nearby annual nonnative vegetation dominated by $B$. tectorum L. ("cheatgrass-dominated" hereafter). Although perhaps not initially identical to the sagebrush plots, all cheatgrass-dominated plots were previously sagebrush-dominated shrub stands that were converted to their current state by a fire in 1998 and subsequent cheatgrass invasion (Dan Washington, Salt Lake Field Office, USDI Bureau of Land Management, personal communication; Eugene W. Schupp unpublished data). All plots occur on the Hiko Peak soil series, where the potential plant community consists of about $45 \%$ perennial grasses, $15 \%$ forbs, and 40\% shrubs dominated by Wyoming big sagebrush (Artemisia tridentata Nutt. ssp. wyomingensis Beetle \& Young; NRCS 2000). To our knowledge, no postfire seeding or other attempts at restoration had occurred at these sites.

Vegetation of sagebrush plots was typical of Wyoming big sagebrush communities of the Great Basin. In addition to Wyoming big sagebrush, the shrubs fourwing saltbush (Atriplex canescens [Pursh] Nutt.), broom snakeweed (Gutierrezia sarothrae [Pursh] Britton \& Rusby), yellow rabbitbrush (Chrysothamnus viscidiflorus [Hook.] Nutt.), and mormon tea (Ephedra viridis Coville) were also present. Interspaces were dominated by the grasses Indian ricegrass (Achnatherum hymenoides [Roem. \& Schult.] Barkworth), squirreltail (Elymus elymoides [Raf.] Swezey), Sandberg bluegrass (Poa 
secunda J. Presl), needle and thread (Hesperostipa comata [Trin. \& Rupr.] Barkworth), basin wildrye (Leymus cinereus $[$ Scribn. \& Merr.] A. Löve), bluebunch wheatgrass (Pseudoroegneria spicata [Pursh] A. Löve), and some B. tectorum. Cheatgrass-dominated plots were primarily B. tectorum ( $\geq 90 \%$ standing biomass-Ostoja unpublished data) but also had other weedy species including Russian thistle (Salsola spp.), tall tumblemustard (Sisymbrium altissimum L.), and peppercress (Lepidium spp.).

\section{Ant Sampling}

In each plot, 25 pitfall traps were placed in a $5 \times 5$ grid with 20 -m spacing between traps. A trap consisted of a steel can $(78 \mathrm{~mm}$ diameter) buried flush with the ground and containing approximately $3 \mathrm{~cm}$ of a 1:1 mixture of animal-safe propylene glycol $\left(\right.$ SIERRA $^{\circledR}$ Antifreeze, Safe Brands Corporation) and water. Traps were baited with peanut butter placed near the inside rim of the can and with onequarter of a Pecan Sandie ${ }^{\circledR}$ cookie crumbled on the ground around the can (Brown 2000). Although Greenslade and Greenslade (1971) suggested that using bait with traps may bias capture rates because of variation in speciesspecific responses, we used bait to increase the likelihood that ants would encounter a trap (Marsh 1986). In addition, because our primary interest was differences in ant communities between vegetation types rather than absolute estimates of relative abundances of the different species, this potential bias would not have affected our results. Trapping occurred on 20-22 June 2004. Traps were set and after 48 hours were retrieved. This duration is considered the minimum trapping period to effectively characterize ant communities (Bestelmeyer et al. 2000, Borgelt and New 2006). Trapped animals were separated from the propylene glycol solution, rinsed in purified water, and cold-stored in 70\% ethanol until identified.

\section{Data Analysis}

Ants were sorted, identified to species using published keys, and counted. Identifications were verified by E. Sarnat of the Department of Entomology at the University of California at Davis. Voucher specimens were deposited at the Plant and Restoration Ecology Lab, Utah State University, and at the
Eastern Oregon Agricultural Research Center, Oregon State University. We positively identified $>99 \%$ of our specimens. All 3 "Formica fusca" specimens considered in our data analyses were identified to the Formica fusca group, but they could not be identified to species with total certainty due to missing critical taxonomic features.

Identified species were assigned to functional groups according to their species-group responses to environmental stress and disturbance, following previous studies of ants as bioindicators (Andersen 1997, Andersen et al. 2002). These groups are dominant Dolichoderinae (DD), cold-climate specialists (CCS), hotclimate specialists (HCS), cryptic species (CrS), opportunists (OPP), generalized Myrmicinae (GM), and subordinate Camponotini (C). See Andersen (1997) for detailed descriptions of functional group designations.

Overall taxon abundances in pitfall traps were first assessed by summing the abundances of a species across the 3 plots in a vegetation type (i.e., cheatgrass-dominated or sagebrush). We used ANOVA to the compare species and functional-group abundances between the 2 vegetation types, using SYSTAT 12 (SYSTAT 2007). To better meet assumptions for ANOVA, pitfall trap data were log transformed. We constructed rank abundance curves in Species Diversity and Richness 3.03 (Pisces Conservation Ltd., www.pisces-conservation.com/ indexsoftdiversity.html) by plotting the species and functional-group abundances (log) against the species rank to determine whether "abundant" or "common" species and/or functional groups respond to cheatgrass conversion in similar ways. Based on patterns observed in the rank abundance curves, we conducted additional contingency table analyses in StatXact 6 (Mehta and Patel 2003) to quantify inferences regarding shifting patterns of abundance to habitat conversion.

Simpson's and Shannon's diversity indices and the Brillouin evenness index were calculated for both vegetation types at both the species and the functional-group levels (Solow 1993, Magurran 2004, 2005, Buckland 2005). We used nonparametric $t$ tests to compare ant species and functional-group diversity and evenness between vegetation types (Magurran 2004, Bestelmeyer 2005). Because different diversity indices vary in their sensitivity to rare species or, conversely, abundant species, 
TABLE 1. Total numbers of ants of identified species captured in pitfall traps by vegetation type. Functional groups of species based on Andersen (2000), Brown (2000), and Bestelmeyer (2005) are also shown.

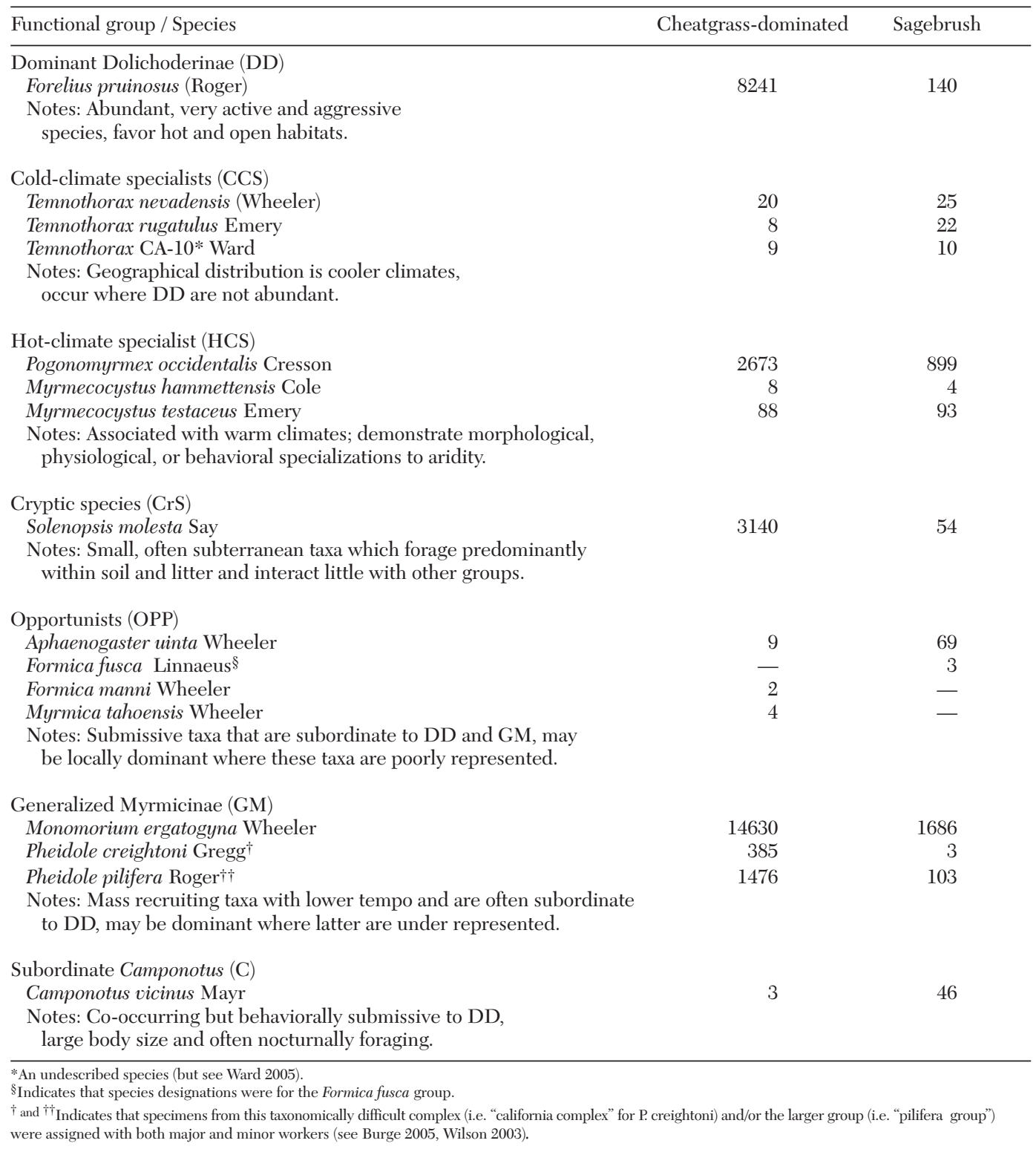

we constructed Rényi curves (Rényi 1961) to help interpret diversity patterns among the habitat types. This method of diversity ordering allows for the interpretation of diversity patterns across a range of indices by plotting index values against the scale parameter to determine, in our case, whether species and/or functional-group diversity may unambiguously differ between habitat types (see Rényi 1961, Hill 1973). Larger Rényi index values (y-axis) suggest greater levels of species diversity at a given point along the scale parameter (x-axis). The scale parameter represents a range of diversity metrics that differ in their sensitivity to abundant species; lower scale parameter $(0,1)$ values give less weight to abundant species than do larger scale parameter values $(3,4)$. All diversity and/or evenness calculations and comparisons were done in Species Diversity and Richness 3.03 (Pisces Conservation Ltd., www.pisces-conservation .com/indexsoftdiversity.html). 
TABLE 2. The Simpson's and Shannon's diversity indices and the Brillouin evenness index by vegetation type at the species and functional-group levels (see Magurran 2004). Significant results $(P \leq 0.05)$ for nonparametric $t$ tests comparing cheatgrass-dominated and sagebrush habitat types are denoted by an asterisk (*). Bold type indicates the habitat type that had greater diversity or evenness.

\begin{tabular}{lcc}
\hline Index & $\begin{array}{c}\text { Cheatgrass- } \\
\text { dominated }\end{array}$ & Sagebrush \\
\hline Species & & \\
Simpson's diversity & 2.570 & 2.665 \\
Shannon's diversity* & 1.192 & $\mathbf{1 . 3 5 3}$ \\
Brillouin evenness & 0.451 & 0.524 \\
Functional group & & \\
Simpson's diversity* & $\mathbf{2 . 7 0 5}$ & 2.272 \\
Shannon's diversity* & $\mathbf{1 . 1 6 9}$ & 1.091 \\
Brillouin evenness* & $\mathbf{0 . 6 0 0}$ & 0.558 \\
\hline
\end{tabular}

Taxa were examined at the species level for richness and other statistical analyses (unless treated as functional groups), allowing for ecological interpretation of taxon-specific responses to vegetation type (Bestelmeyer 2005). Significance for all analyses was accepted at $\alpha=$ 0.05. Because all data were collected at the southern end of the Rush Valley region, statistical inferences are limited to the study area (Wester 1992).

\section{Results AND Discussion}

Patterns of Richness, Diversity, and Abundance

In contradiction to our first prediction, ant species richness was similar between the 2 vegetation types. Sixteen species were identified in this study, 15 in cheatgrass-dominated plots and 14 in sagebrush plots, with 13 trapped in both vegetation types (Table 1). However, measures of diversity and evenness at the individual species level and the functionalgroup level differed between the habitat types (Table 2). At the species level, Shannon's diversity index indicated that sagebrush plots were significantly more diverse than were cheatgrass-dominated plots. In contrast, at the functional-group level, both Simpson's and Shannon's diversity indices revealed significantly greater diversity in the cheatgrass-dominated plots. Similarly, functional-group Brillouin evenness was also significantly greater in cheatgrass-dominated plots (Table 2). However, examination of the Rényi diversity ordering curves yields a more complex conclusion
(Fig. 1). When more abundant species or functional groups are weighted more heavily (higher scale parameter values) cheatgrass-dominated plots are more diverse, but when abundant species or functional groups are given less weight (lower scale parameter values), sagebrush plots are more diverse. The resulting crossings of the curves (Fig. 1) reveal that species diversity was not wholly greater in sagebrush plots than in cheatgrass-dominated plots and that functional-group diversity was not wholly greater in cheatgrass-dominated plots than in sagebrush plots.

Limited research suggests that cheatgrassdominated sites are a less-suitable habitat type than sagebrush sites for some other groups of animals (birds-Knick and Rotenberry 2000; small mammals_Gano and Rickard 1982, Ostoja 2008; lizards-Green et al. 2001, Newbold 2005a, 2005b; and snakes-John Mull personal communication) in the Intermountain West. If the present results reflect patterns across a broader geographic range, at least in terms of species diversity and evenness, ant communities may not respond negatively to site conversion to cheatgrass. However, a closer consideration of species and functionalgroup responses provides a more complete understanding of how cheatgrass conversion appears to affect ant communities.

Total ant abundance differed significantly between the 2 vegetation types, but in a pattern opposite to our first prediction: ants were about 10-fold more abundant in cheatgrassdominated plots $\left(10,342, s_{\bar{x}}=682\right)$ than in sagebrush plots $\left(1075, s_{\bar{x}}=112 ; F_{1,4}=179.5\right.$; $P<0.001)$. At the individual species level, 6 species were significantly more abundant in cheatgrass-dominated plots while 3 were significantly more abundant in sagebrush plots (Fig. 2). In both cheatgrass-dominated and sagebrush plots, the most abundant species was Monomorium ergatogyna, which was one order of magnitude more abundant than the second-most common species (Table 1, Fig. 2).

The abundances of all 7 functional groups differed significantly between intact sagebrush and cheatgrass-dominated communities (Fig. 3). Interestingly, the patterns of abundances across the vegetation types appear to be related to whether the groups were relatively common versus relatively uncommon. Three of the 4 functional groups with the fewest captures in intact-sagebrush plots (CCS, 


\section{Rényi Diversity Ordering}

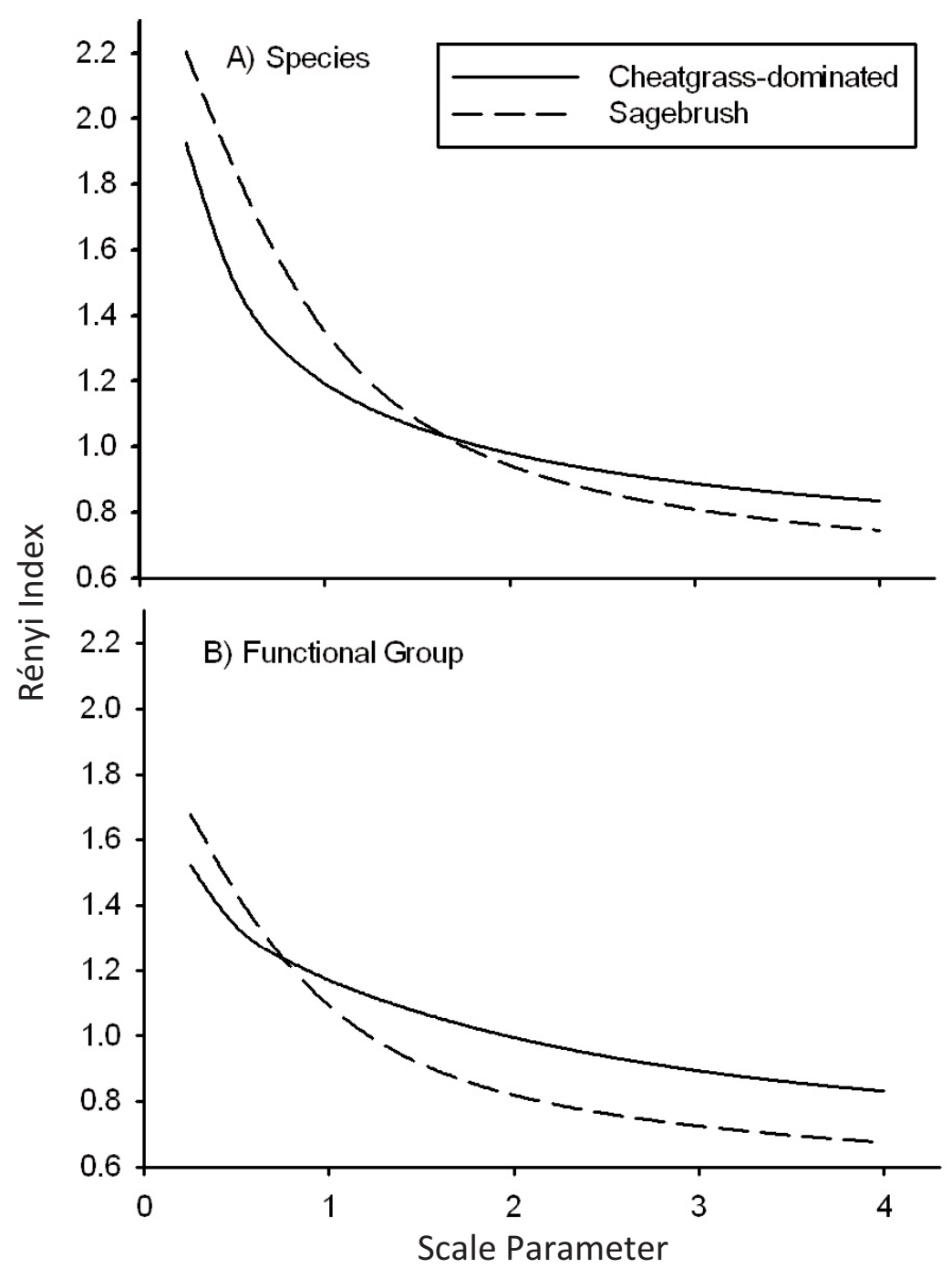

Fig. 1. Diversity ordering of Rényi curves based on plotting the Rényi index against the scale parameter for the species level (A) and the functional-group level (B) for cheatgrass-dominated and sagebrush plots. Greater Rényi index values suggest greater diversity for a given population at any given scale parameter. The scale parameters are differing diversity indices with 0 representing species number, 1 representing Shannon's $H, 2$ representing Simpson's $D$, and so on. With increasing scale parameter values, more abundant species/functional groups are progressively weighted more heavily.

OPP, and C) were significantly less abundant in cheatgrass-dominated plots compared to sagebrush plots (Fig. 3). In contrast, all 3 of the more-abundant functional groups in intactsagebrush plots (DD, HCS, and GM) and only 1 of the 4 less-abundant groups (CrS) were significantly more abundant in cheatgrassdominated plots than in sagebrush plots (Fig. 3). This pattern is graphically corroborated by the patterns of the rank abundance curves for functional groups, where the cheatgrass-dominated curve lies above the sagebrush curve at higher rank-order abundances but then drops below the sagebrush curve at lower rankorder abundances (see Fig. 4B).

Similar, though less extreme, results are seen at the species level (Fig. 4A). To further assess these patterns, we considered a species to be 


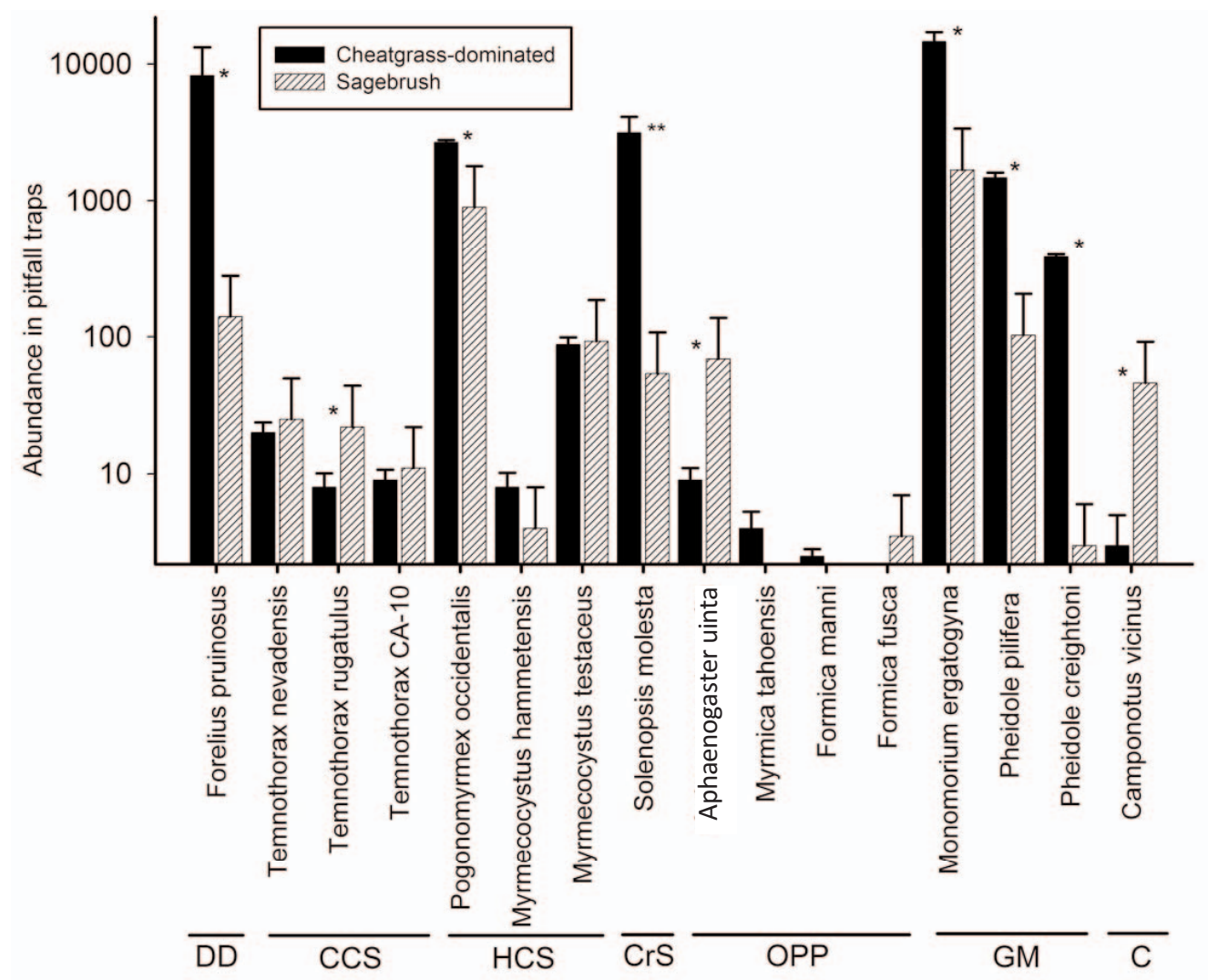

Fig. 2. Means (bars represent standard errors) of abundances in pitfall traps by species in cheatgrass-dominated and sagebrush plots. $* *=P \leq 0.001, *=P \leq 0.05$ for ANOVA tests. Functional groups: DD $=$ dominant Dolichoderinae, $\mathrm{GM}=$ generalized Myrmicinae, $\mathrm{C}=$ subordinate Camponotus, $\mathrm{CCS}=$ cold-climate specialists, $\mathrm{CrS}=$ cryptic species, HCS = hot-climate specialists, OPP = opportunists; see Table 1 for descriptions of functional groups.

uncommon if fewer than 100 individuals were captured in total across all 6 plots and common if more than 100 individuals of that species were captured. Although not a biologically-based definition of common, this categorization was chosen because it roughly divides the data set in half, while basing the cutoff on the first relatively large jump in abundances (from 78 to 181 total captures). With these criteria, 6 of 9 uncommon species were more abundant in sagebrush plots, while 6 of 7 common species were more abundant in cheatgrass-dominated plots (Table 1). Although this analysis was somewhat arbitrary and not quite significant in a $2 \times 2$ exact contingency table analysis $(P$ $\left.=0.051, \chi^{2}=4.39, \mathrm{df}=1\right)$, this result is compatible with other evidence such as the rankabundance curves. Overall, evidence strongly suggests that more-common species and functional groups are more likely to be favored by cheatgrass conversion, while less-common species and functional groups are more likely to be adversely affected by cheatgrass conversion.

The greater overall ant abundance in cheatgrass-dominated plots may be related to differences in resource availability and/or to competitive release due to rodent granivores being less abundant and diverse in cheatgrassdominated than in intact sagebrush communities in this region (Ostoja 2008). Although data on ants are not available, grasshopper assemblages in sites dominated by annual vegetation (predominately cheatgrass) had relatively high densities of some species, which the authors attributed to these species' preference for cheatgrass as food (Fielding and Brusven 1992, 1993). Data on resource availability and use are insufficient for us to make strong conclusions about our study system in its entirety. Increased resource availability due to 


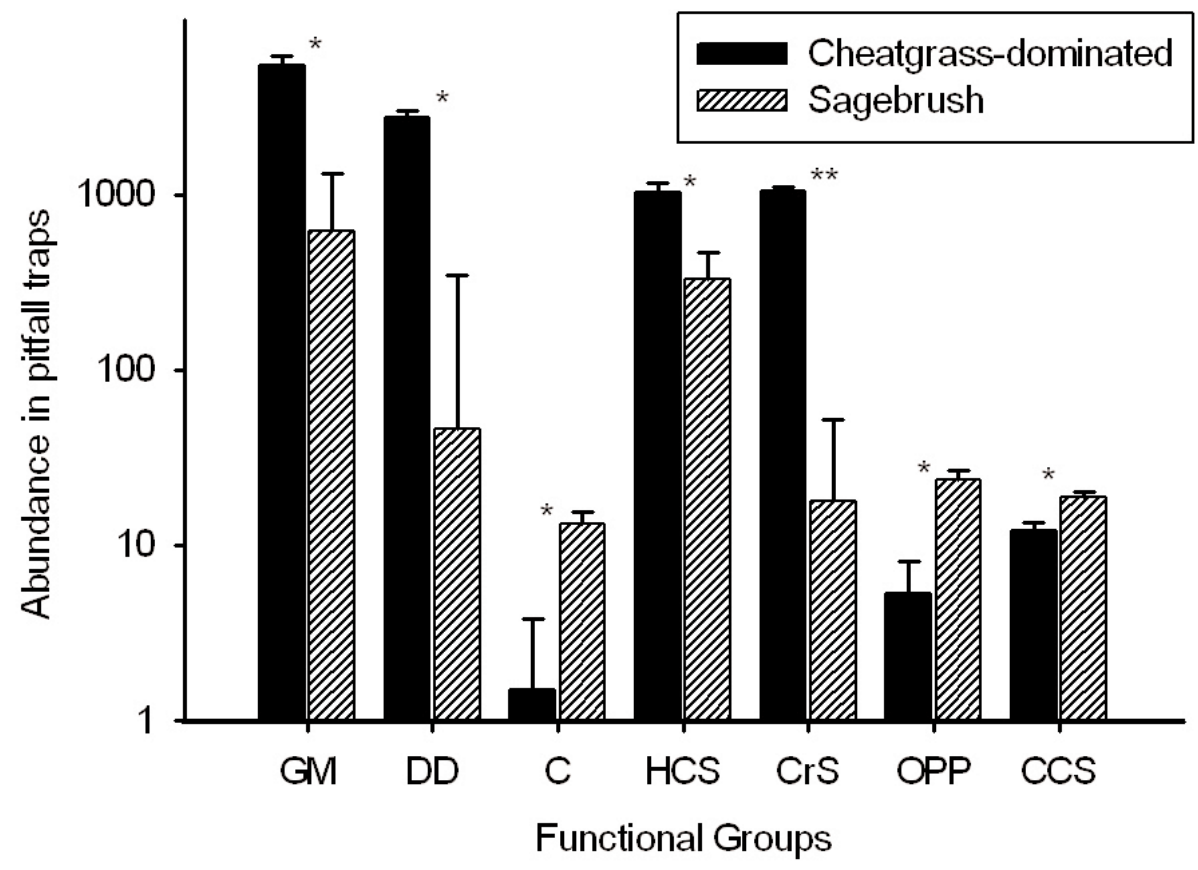

Fig. 3. Means (error bars represent standard errors) of abundances in pitfall traps by functional group in cheatgrassdominated and sagebrush plots. $* *=P \leq 0.001,{ }^{*}=P \leq 0.05$ for ANOVA tests. Functional groups: DD $=$ dominant Dolichoderinae, $\mathrm{GM}=$ generalized Myrmicinae, $\mathrm{C}=$ subordinate Camponotus, $\mathrm{CCS}=$ cold-climate specialists, $\mathrm{CrS}=$ cryptic species, HCS = hot-climate specialists, OPP = opportunists; see Table 1 for descriptions of functional groups.

a combination of differences in seed production and competitive release may be at least partially responsible for the greater abundance of seed-harvesting ants such as Pogonomyrmex spp. and Pheidole spp. in cheatgrassdominated communities. Although data are not extensive, cheatgrass-dominated stands in the Great Basin can have seed bank densities in excess of 4000 or even 12,000 seeds $\cdot \mathrm{m}^{-2}$ (e.g., Humphrey and Schupp 2001), while intact sagebrush-steppe communities appear to have seed banks 1-2 orders of magnitude lower than cheatgrass-dominated stands (e.g., Anderson and MacMahon 2001). Moreover, rodents have lower species richness and abundance in cheatgrass-dominated communities compared to nearby intact sagebrush vegetation (Ostoja 2008). Seed-harvesting ants might thus increase in abundance due to higher seed production and reduced competition from granivorous rodents (Davidson et al. 1980). Aridland ants and rodents are reported to have extensive diet overlap (suggestive of resource competition among rodents and ants; see Brown and Davidson 1977), a pattern corroborated in our region with seed removal tri- als for both groups (Ostoja 2008).

Other factors such as edaphic characteristics and natural enemies could also contribute to the relatively low abundances of $P$. occidentalis and other ant species in sagebrush sites. Ants in desert habitats have strong interactions with many organisms (MacMahon et al. 2000). As noted by Andersen (1997) and Andersen et al. (2002), the diversity of interactions suggests that environmental variation in ecosystem structure may be reflected in ant community composition. For example, Bestelmeyer and Wiens (2001) found that ant abundance and/or diversity was influenced more by the vegetation community and soil texture than by the disturbance histories of sites. However, such considerations were beyond the scope of this study.

Considering differences between communities in ant species abundance in terms of the biology of the functional groups may provide additional insight into the patterns (Fig. 3). For example, particularly in warmer climates of North America, the DD are considered to be active and aggressive species while other functional groups (i.e., OPP and CCS) are 


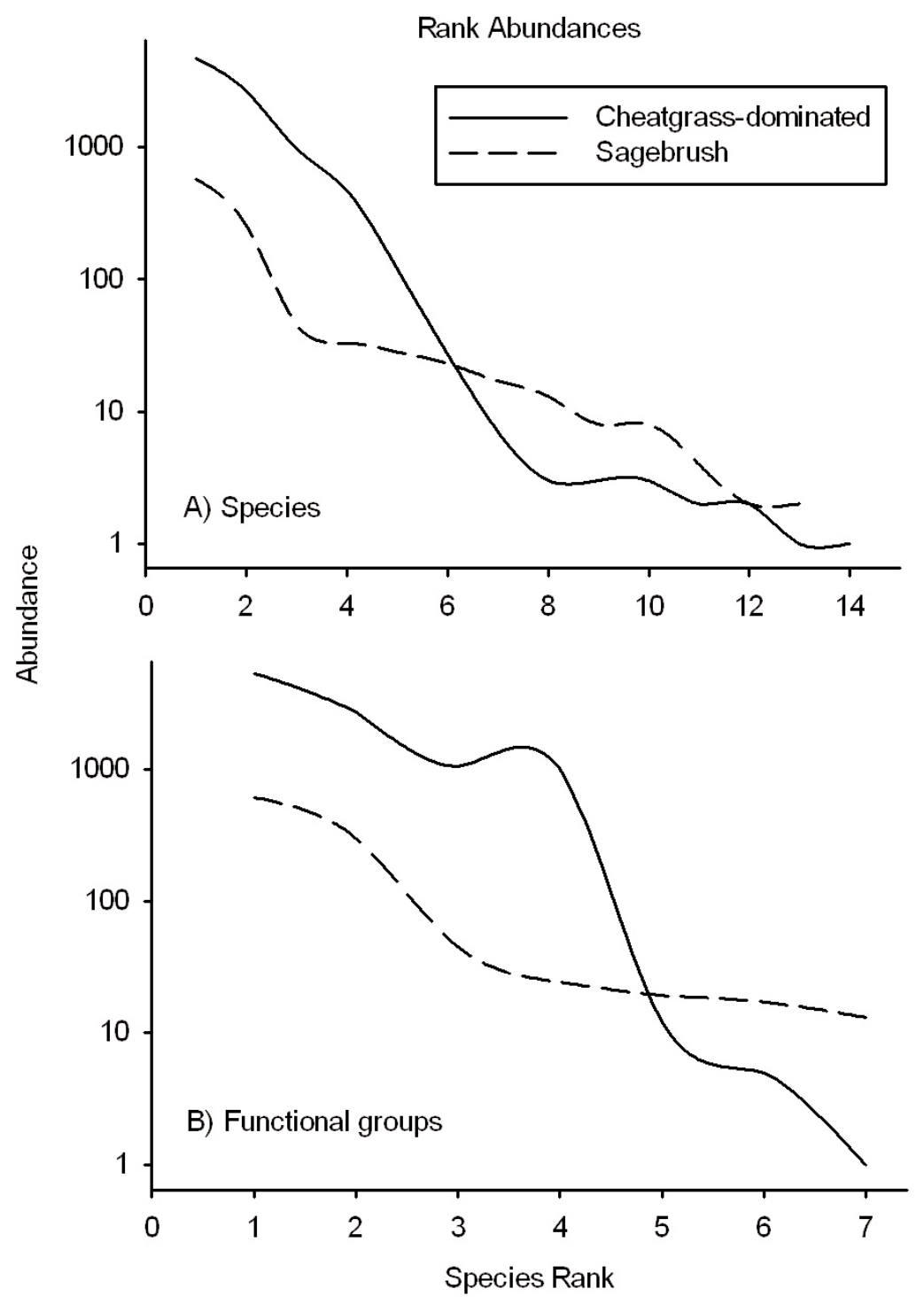

Fig. 4. Rank abundance curves depicting the species abundance on a log scale against rank order for the species level (A) and the functional-group level (B) for cheatgrass-dominated and sagebrush plots. Note that abundant species and functional groups in the native sagebrush plots become more abundant in cheatgrass-dominated plots, while the groups demonstrating low abundance in sagebrush become even less abundant with habitat conversion.

reported to be subordinate and/or to occur where the DD are not abundant (Andersen 1997). With a marked relative increase in the abundance of DD in cheatgrass-dominated plots, all 3 species within the CCS in those plots had relatively lower abundances, as would be expected (Fig. 2). Similarly, although all species of opportunists (i.e., OPP) had low abundances everywhere, one species, Aphaenogaster uinta, was significantly more abundant in sagebrush than in cheatgrass-dominated plots. The GM, which are thought to be behaviorally dominant to the DD, were in fact more abundant than the DD functional group in both vegetation types (Andersen 1997). Thus, there is evidence that something about the biology of species interactions and use of resources by functional groups likely drives not only community structuring of functional groups in general but also their responses to cheatgrass conversion. However, 
continued research is necessary to untangle the suite of potential factors affecting the observed ant-community changes. We suggest that the results of this study be considered in the context of the experimental design and limited scope of the study area. A more comprehensive evaluation of invertebrate responses to cheatgrass conversion conducted over a larger area and longer period is suggested.

\section{Restoration, Conservation, and Management Implications}

Restoration of cheatgrass-dominated communities to big sagebrush is occurring throughout semiarid regions of the western United States, often through the application of seed. Thus, it is important to understand how seedharvesting species such as Pogonomyrmex spp. and Pheidole spp. are affected by conversion to cheatgrass. All species within these seed-harvesting genera were more abundant in cheatgrass-dominated plots than in sagebrush plots. This can have important implications where aerial broadcast seeding is used. Some species of Pogonomyrmex are reported to remove 10\% of annual seed production, although they may remove $100 \%$ of more-preferred seed types (Crist and MacMahon 1992, Mull and MacMahon 1997, MacMahon et al. 2000). Pogonomyrmex occidentalis is the most conspicuous ant in both habitats, but it is especially abundant in cheatgrass-dominated plots. Moreover, this species has a greater mound density in cheatgrass-dominated habitats than in any of 7 other vegetation types in the area, including intact sagebrush (Tyler Logan unpublished data). Overall, these results suggest that predation on desirable seeds by ants might be a significant problem for aerial seeding efforts in cheatgrassdominated sites. However, because ants cannot locate and harvest buried seeds, predation should be less of a problem for drilled seeds (MacMahon et al. 2000).

The shifts in ant communities found in this study could be happening at larger scales throughout the Intermountain West, where cheatgrass conversion is occurring at an alarming rate. However, given the limited research on how cheatgrass conversion may be affecting other invertebrate groups, it is difficult to assess whether these ant results represent what other groups are experiencing. Potentially, rare ant species may be threatened by cheatgrass conversion, as the observations reported here suggest that rare species are more likely than common species to be negatively impacted by this habitat conversion. Because changes to other environmental factors (i.e., soil morphology, soil microbial communities, and the fire cycle) occur with cheatgrass conversion, it is difficult to know which direct or indirect factors favor some species while harming others (Belnap et al. 2005, 2006). These results suggest that the effects of invasion on biodiversity may not be wholly negative per se, but they point to the continued need to assess animal communities in the face of a changing landscape.

\section{ACKNOWLEDGMENTS}

Thanks go to Julie Rieder and Scott Newbold for field assistance and to Eli Sarnat for verifying ant identifications and preparing ant specimens in the laboratory. Karen Beard, Chris Call, James MacMahon, and Tom Monaco provided helpful comments. Leticia RiosCasanova, Rob Klinger, and an anonymous reviewer helped improve earlier versions of this manuscript. This research was supported by the Cooperative State Research, Education, and Extension Service, U.S. Department of Agriculture, under Agreement No. 200152103-11322; the Utah Agricultural Experiment Station (UAES), Utah State University, Logan; a Utah State University Ecology Center research fellowship; and a Utah State University School of Graduate Studies dissertation fellowship. This manuscript was approved as UAES journal paper no. 7965 .

\section{Literature Cited}

ANDERSEN, A.N. 1997. Functional groups and patterns of organization in North American ant communities: a comparison with Australia. Journal of Biogeography $24: 433-460$.

Andersen, A.N., B.D. Hoffmann, W.J. Muller, and A.D. GRIFFITHS. 2002. Using ants as bioindicators in land management: simplifying assessment of ant community responses. Journal of Applied Ecology 39:8-17.

Andersen, A.N., AND J.D. Majer. 2004. Ants show the way down under: invertebrates as bioindicators in land management. Frontiers in Ecology and the Environment 2:291-298.

Andersen, A.N., AND G.P. Sparling. 1997. Ants as indicators of restoration success: relationship with soil microbial biomass in the Australian seasonal tropics. Restoration Ecology 5:109-114.

Anderson, C.J., and J.A. MacMahon. 2001. Granivores, exclosures, and seed banks: harvester ants and rodents in sagebrush-steppe. Journal of Arid Environments 49:343-355. 
Belnap, J., S.L. Phillips, S.K. Sherrod, and A. MoldENKE. 2005. Soil biota can change after exotic plant invasion: does this affect ecosystem processes? Ecology 86:3007-3017.

Belnap, J., S.L. Phillips, and T. Troxler. 2006. Soil lichen and moss cover and species richness can be highly dynamic: the effects of invasion by the annual exotic grass Bromus tectorum, precipitation, and temperature on biological soil crusts in SE Utah. Applied Soil Ecology 32:63-76.

Bestelmeyer, B.T. 2005. Does desertification diminish biodiversity? Enhancement of ant diversity by shrub invasion in south-western USA. Diversity and Distributions 11:45-55.

Bestelmeyer, B.T., D. Agosti, L.E. Alonso, R. Roberto, C. Brandaeo, W.L. Brown, Jr., J.H.C. Delabie, and R. SiLvestRe. 2000. Field techniques for the study of ground-dwelling ants. Pages 122-144 in D. Agosti, J.D. Majer, L.E. Alonso, and T.R. Schultz, editors, Ants: standard methods for measuring and monitoring biodiversity. Smithsonian Institution Press, Washington, DC.

Bestelmeyer, B.T., and J.A. Wiens. 1996. The effects of land use on the structure of ground-foraging ant communities in the Argentine Chaco. Ecological Applications 6:1225-1240.

2001. Ant biodiversity in semiarid landscape mosaics: the consequences of grazing vs. natural heterogeneity. Ecological Applications 11:1123-1140.

BilLings, W.D. 1990. Bromus tectorum, a biotic cause of ecosystem impoverishment in the Great Basin. Pages 301-320 in G.M. Woodwell, editor, The Earth in transition: patterns and processes of biotic impoverishment. Cambridge University Press, New York.

BorgeLt, A., AND T.R. NEW. 2006. Pitfall trapping for ants (Hymenoptera, Formicidae) in mesic Australia: what is the best trapping period? Journal of Insect Conservation 10:75-77.

Brooks, M.L., C.M. D’Antonio, D.M. Richardson, J.B. Grace, J.E. Keeley, J.M. DiTomaso, R.J. Hobbs, M. Pellant, and D.A. Pyke. 2004. Effects of invasive alien plants on fire regimes. BioScience 54:677-688.

Brown, J.H., and D.W. Davidson. 1977. Competition between seed-eating rodents and ants in desert ecosystems. Science 196:880-882.

Brown, W.L., JR. 2000. Diversity of ants. Pages 45-79 in D. Agosti, D.J. Majer, L. Alonso, and T. Schulz, editors, Ants: standard methods for measuring and monitoring biodiversity. Smithsonian Institution Press, Washington, DC.

BuckLand, S.T., A.E. MagurRan, R.E. Green, and R.M. FEWSTER. 2005. Monitoring change in biodiversity through composite indices. Philosophical Transactions of the Royal Society. Series B, Containing Papers of a Biological Character 360:243-254.

Burge, D.O. 2005. Taxonomy, biology, and distribution of seed harvesting ants in the Pheidole californica complex (Hymenoptera: Formicidae). Journal of Hymenoptera Research 14:137-150.

Crisp, P.N., K.M. Dickinson, AND G.W. Gibbs. 1998. Does native invertebrate diversity reflect native plant diversity? A case study from New Zealand and implications for conservation. Biological Conservation 83:209-220.

Crist, T.O., AND J.A. MaCMAHON. 1992. Harvester ant foraging and shrub-steppe seeds: interactions of seed resources and seed use. Ecology 73:1768-1779.
D’Antonio, C.M., And P.M. Vitousek. 1992. Biological invasions by exotic grasses, the grass/fire cycle, and global change. Annual Review of Ecology and Systematics 23:63-87.

Davidson, D.W., J.H. Brown, and R.S. Inouye. 1980. Competition and the structure of granivore communities. BioScience 30:233-238.

Fielding, D.J., AND M.A. BRusven. 1992. Food and habitat preferences of Melanoplus sanguinipes and Aulocara elliotti (Orthoptera, Acrididae) on disturbed rangelands in southern Idaho. Journal of Economic Entomology 85:783-788.

1993. Grasshopper (Orthoptera, Acrididae) community composition and ecological disturbance on southern Idaho rangeland. Environmental Entomology $22: 71-81$.

FLeIschner, T.L. 1994. Ecological costs of livestock grazing in western North America. Conservation Biology 8:629-644.

GANO, K.A., AND W.H. RiCKARD. 1982. Small mammals of a bitterbrush-cheatgrass community. Northwest Science $56: 1-7$.

Green, G.A., K.B. Livezey, and R.L. Morgan. 2001. Habitat selection by northern sagebrush lizards (Sceloporus graciosus graciosus) in the Columbia Basin, Oregon. Northwestern Naturalist 82:111-115.

Greenslade, P., and J.M. Greenslade. 1971. The use of baits and preservatives in pitfall traps. Journal of the Australian Entomological Society 10:253-260.

HILL, M.O. 1973. Diversity and evenness: a unifying notation and its consequences. Ecology 54:427-432.

Hoffmann, B.D., And A.N. Andersen. 2003. Responses of ants to disturbance in Australia, with particular reference to functional groups. Austral Ecology 28:444-464.

Humphrey, L.D., AND E.W. Schupp. 2001. Seed banks of Bromus tectorum-dominated communities in the Great Basin. Western North American Naturalist 61:85-92.

King, J.R., A.N. ANDERSEN, AND A.D. CutTer. 1998. Ants as bioindicators of habitat disturbance: validation of the functional group model for Australia's humid tropics. Biodiversity and Conservation 7:1627-1638.

KNAPP, P.A. 1996. Cheatgrass (Bromus tectorum L) dominance in the Great Basin Desert-history, persistence, and influences to human activities. Global Environmental Change: Human and Policy Dimensions $6: 37-52$.

KNICK, S.T., AND J.T. RotenberRY. 2000. Ghosts of habitats past: contribution of landscape change to current habitats used by shrubland birds. Ecology 81:220-227.

Koricheva, J., C. Mulder, B. Schmid, J. Joshi, and K. Huss-DANELL. 2000. Numerical responses of different trophic groups of invertebrates to manipulations of plant diversity in grasslands. Oecologia 125:271-282.

Link, S.O., C.W. Keeler, R.W. Hill, and E. Hagen. 2006. Bromus tectorum cover mapping and fire risk. International Journal of Wildland Fire 15:113-119.

MacMahon, J.A., J.F. Mull, and T.O. CRist. 2000. Harvester ants (Pogonomyrmex spp.): their community and ecosystem influences. Annual Review of Ecology and Systematics 31:265-291.

MagurRan, A.E. 2004. Measuring ecological diversity. Blackwell Publishing, Oxford, U.K. 256 pp.

. 2005. Species abundance distributions: pattern or process? Functional Ecology 19:177-181.

Marsh, A.C. 1986. Ant species richness along a climatic gradient in the Namib Desert. Journal of Arid Environments 11:235-241. 
Mehta, C., and N. Patel. 2003. StatXact 6. Statistical software for exact nonparametric inference. Cytel Software Corporation, Cambridge, MA.

MulL, J.F., AND J.A. MACMAHON. 1997. Spatial variation in rates of seed removal by harvester ants (Pogonomyrmex occidentalis) in a shrub-steppe ecosystem. American Midland Naturalist 138:1-13.

Murdoch, W.W., F.C. Evans, and C.H. Peterson. 1972. Diversity and pattern in plants and insects. Ecology 53:819-829

[NRCS] Natural Resources Conservation Service. 2000. Soil survey of Tooele area, Utah. Washington DC. vii +269 pp.

Newbold, T.A.S. 2005a. Biotic and abiotic determinants of species distribution: desert horned lizards (Phrynosoma platyrhinos) and ants in a shrub-steppe ecosystem. Doctoral dissertation, Utah State University, Logan.

2005b. Desert horned lizard (Phrynosoma platyrhinos) locomotor performance: the influence of cheatgrass (Bromus tectorum). Southwestern Naturalist 50:17-23.

NovaK, S.J., AND R.N. Mack. 2001. Tracing plant introduction and spread: genetic evidence from Bromus tectorum (cheatgrass). BioScience 51:114-122.

Osтоja, S.M. 2008. Granivores and restoration: implications of weed invasion and context-dependent seed removal. Doctoral dissertation, Utah State University, Logan.

Pellant, M. 1989. The cheatgrass-wildfire cycle-are there any solutions? Pages 11-18 in E.D. McArthur, E.M. Romney, S.D. Smith, and P.T. Tueller, editors, Symposium on cheatgrass invasion, shrub die-off, and other aspects of shrub biology management. USDA Forest Service, Las Vegas, NV.

Perner, J., C. Wytrykush, A. Kahmen, N. Buchmann, I. Egerer, S. Creutzburg, N. Odat, V. Audorff, and W.W. WEISSER. 2005. Effects of plant diversity, plant productivity and habitat parameters on arthropod abundance in montane European grasslands. Ecography 28:429-442.

Pimentel, D., L. Lach, R. Zuniga, and D. Morrison. 2000. Environmental and economic costs of non- indigenous species in the United States. BioScience 50:53-65.

RÉNYI, A. 1961. On measures of entropy and information. Pages 547-561 in J. Neyman, editor, Proceedings of the 4th Berkeley Symposium on Mathematical Statistics and Probability. Volume 1. University of California Press, Berkeley.

SoLow, A.R. 1993. A simple test for change in community structure. Journal of Animal Ecology 62:191-193.

SYSTAT. 2007. SYSTAT 12. SYSTAT Software, Inc., San Jose, CA.

Tews, J., U. Brose, V. Grimm, K. Tielborger, M.C. Wichmann, M. Schwager, and F. Jeltsch. 2004. Animal species diversity driven by habitat heterogeneity/diversity: the importance of keystone structures. Journal of Biogeography 31:79-92.

VALE, T.R. 1975. Pre-settlement vegetation in the sagebrush grass area of the Intermountain West. Journal of Range Management 28:32-36.

WARD, S.P. 2005. A synoptic review of the ants of California (Hymenoptera: Formicidae). Zootaxa 936:1-86.

WENNINGER, E.J., AND R.S. INOUYE. 2008. Insect community response to plant diversity and productivity in a sagebrush-steppe ecosystem. Journal of Arid Environments 72:24-33.

Wester, D.B. 1992. Viewpoint: replication, randomization, and statistics in range science. Journal of Range Management 45:285-290.

Wilson, E.O. 2003. Pheidole in the New World, a hyperdiverse ant genus. Harvard University Press, Cambridge, MA. $794 \mathrm{pp}$.

Wirth, A.T., AND D.A. Pyke. 2003. Restoring forbs for sage grouse habitat: fire, microsites, and establishment methods. Restoration Ecology 11:370-377.

Yensen, E., D.L. Quinney, K. Johnson, K. Timmerman, AND K. SteEnhof. 1992. Fire, vegetation changes, and population fluctuations of Townsend's Ground Squirrels. American Midland Naturalist 128:299-312.

Received 7 March 2008 Accepted 3 December 2008 